\title{
軽量骨材を用いたコンクリートの細孔構造に及ぼす諸要因とその影響 EFFECTS OF FACTORS ON POROSITY OF LIGHTWEIGHT AGGREGATE CONCRETE
}

\author{
小山明男*1, 菊池雅史*2, 三浦隆広*3 \\ Akio KOYAMA, Masafumi KIKUCHI and Takahiro MIURA
}

\begin{abstract}
Porosity of concrete was varied by the influence of water cement ratio, curing method, age and so on. The influence, which porosity has on properties of concrete, of lightweight aggregate concrete tends to be stronger than that of normal weight concrete.

From this point of view, porosity of lightweight concrete which varied factors such as water cement ratio, curing method, age, types of aggregate and sampling place, was measured. These results are summarized as follows, a) Changes in contained moisture of concrete are much influenced by water cement ratio and moisture content of aggregate, in the case that be used light weight aggregate, it depends on characteristics of aggregate, surface texture and void connection. b) Under drying condition, effects of types of aggregate on pore structure are varied by water cement ratio, and the densification of pore structure of light weight aggregate concrete tends to be possible at inner place. c) Water contained in lightweight aggregate gives influence to porosity of mortar matrix under drying condition. It depends on rate of exhalation in aggregates. The densification of pore structure of fly-ash aggregate concrete is possible within $2.0 \mathrm{~cm}$ from the drying surface.
\end{abstract}

Keywords : Porasity, , Artificial light weight aggregate, Light weight aggregate concrete, Curing method, Water cement ratio 細孔構造、人工軽量骨材、軽量コンクリート、養生方法、水セメント比

\section{1.はじめに}

硬化したコンクリートの品質に最も大きな影響を及ぼす要因は水 セメント比であり、十分な水湿分の供給下では水和反応の進行にと もない種々の性能が発現されていくことになる。しかし、水湿分の 供給が不十分であったり、発散の程度および速度が大きい場合には 必ずしも所要の性能が確保されない場合がある。この理由としては 水和反态の停滞によるところが大きい。

コンクリートの細孔構造は硬化後の品質を決定づける重要な因子 であり、水セメント比、セメント種類、混和材の混入、材齡などが 細孔構造に及ぼす影響について、あるいは圧縮強度、耐凍結融解性 などの硬化後の諸物性と細孔構造の関係については内川ら ${ }^{1)}$ 、あるい

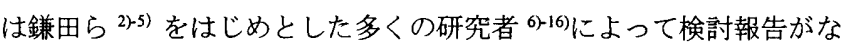
されている。また、水湿分の供給が不十分な乾燥下でのコンクリー トの細孔構造について地濃ら 11)あるいは湯浅ら 12)は詳細に検討さ れており、マトリックス中の含水状態と関係が深く、より乾燥をう ける表層部において水和反応の停滞により組織の緻密化が鈍ること を指摘している。

筆者らはかねてより各種人工軽量骨材を用いたコンクリートの諸 物性に関する検討 ${ }^{17-21)}$ )を進めてきているが、これまでの結果では水 分の発散量や速度が及ぼす影響の程度が普通コンクリートと異なる ことを確認している。普通骨材に比べて吸水率の大きい軽量骨材を
用いたコンクリートでは乾燥下での水分発散量や速度が普通コンク リートと大きく異なり、また内部構造、表面性状などの異なる 2 種 類の軽量骨材の間にも僅かではあるが乾燥による影響が認められて いる。骨材種類によりマトリックス中の含水状態は異なることから、 モルタルマトリックスと骨材中の相対的な環境（湿度）の違いによ って、骨材種類の違いがモルタルマトリックスの細孔構造に影響を 及ぼすことが考えられる。しかし、これら骨材特性と細孔構造の関 係を検討した例は少ない。

そこで本研究では、水セメント比、材齢、採取位置、粗骨材種類、 養生方法の因子を変化させたセメントペーストおよびコンクリート を作製し、これらの各因子が細孔構造に及ぼす影響を粗骨材の種類 を中心に検討したものである。

\section{2. 実験の概要}

\section{2-1. 使用材料}

セメントは、普通ポルトランドセメント $\left(\mathrm{K}_{28}: 428 \mathrm{kgf} / \mathrm{cm}^{2}\right)$ を用いた。 骨材は、粗骨材として硬質砂岩砕石（記号：G）ならびに膨張頁岩系 (記号：L）および石炭灰系（記号：F）の軽量骨材 2 種類合計 3 種 類を用いた。細骨材は、いずれのコンクリートにおいても川砂を用 いた。これら使用骨材の主要物性を表-1に示す。混和剤は、高性能 減水羭（高縮合トリアジン系）、 $\mathrm{AE}$ 減水剤（リグニンスルフォン酸

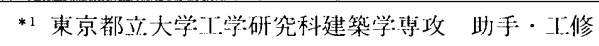

*2 明治大学理二学部建築学科 助教授・ 工博

*3 明治大学大学院理工学研究科建筑学専攻

大学院博 $\mathrm{t}$ : 後期課程 - - 1. 修
Research Assoc., Graduate School of Engineering, Tokyo Metropolitan Univ., M. Eng.

Assoc. Prof., Dept. of Architecture, Science and Technology, Meiji Univ., Dr. Eng. Graduate School of Science and Technology, Meiji Univ., M. Eng. 
系）および空気連行補助剤（樹脂酸系）を用いた。練り混ぜ水は、 一般の上水道を用いた。

\section{2-2. 試料の種類および試験体形状・寸法}

セメントペーストは、水セメント比 $35 \% 、 45 \% 、 55 \%$ の 3 水隻とし 養生方法を 3 水準とした組み合わせにより計 9 種類用意した。なお、 いずれのセメントペーストにおいても混和剤は使用していない。ま た、コンクリートは、粗骨材を 3 種類、水セメント比 3 水準、およ び養生方法 5 水準の組み合わせにより計 45 種類用意した。試料の種 類および調合概略を表-2 に示す。計画調合において単位水量および 細骨材率をそれぞれ $170 \mathrm{~kg} / \mathrm{m}^{3} 、 45 \%$ で一定とし、目標スランプおよ び空気量はそれぞれ $18 \mathrm{~cm} 、 5 \%$ とした。ポロシチー測定試料用の試 験体は $\phi 10 \times 20 \mathrm{~cm}$ の円柱供試体を用いた。なお、セメントペースト では脱型後速やかに $\phi 10 \times 20 \mathrm{~cm}$ の供試体から切り出した $\phi 10 \times 3 \mathrm{~cm}$ のセメントペースト硬化体の上下面にエポキシ樹脂をシールし水分 の発散を防いだものを 2 次養生に供した。

\section{2-3. 養生方法}

セメントペーストおよびコンクリート打設後 24 時間経過時に速や かに脱型を行い、2 次養生を行った。2 次養生は、全材齢水中（記号： A）養生、1 週水中以後気中（記号：B）養生、全材齡気中（記号： C）養生、全材齢封縅（記号 :D）養生、4 週水中以後気中（記号 : E) 養生の 5 水準とした。 なお、気中養生は温度 $20^{\circ} \mathrm{C}$ 、湿度 $\mathrm{RH} 60 \%$ の室 内において行った。なお、セメントペーストについては全材齱水中 養生、 1 週水中以後気中養生、全材齢気中養生の 3 水準のみとした。 2-4. 試料の採取、調整および試験方法 a)試料の採取方法

セメントペースト硬化体試料は、所定材龄に達した後図-1 示す試 料採取位置に分け、 $5 \mathrm{~mm}$ 角程度の試料を採取した。

コングリート試料は、所定材齢に達した時点でコンクリートカッ ターにより上下面 $5 \mathrm{~cm}$ を取り除いた部分を $\phi 10 \times 2 \mathrm{~cm}$ のディスク状 に切断した後図-1 示す試料採取位置に分け、ペーストリッチな部分 から $5 \mathrm{~mm}$ 角程度のモルタル片を採取した。

b)試料の調整方法

採取直後試験管に入れた試料をアセトンに浸し、0.5、4 時間後にそ れぞれアセトンの交換を行い、計 24 時間アセトン処理し水和進行を 停止させた。次に、真空ポンプ $\left(7.5 \times 10^{-3} \mathrm{mmHg}\right)$ により 24 時間脱 水乾燥を行い、ポロシチー測定まで試験管において密封保管した。

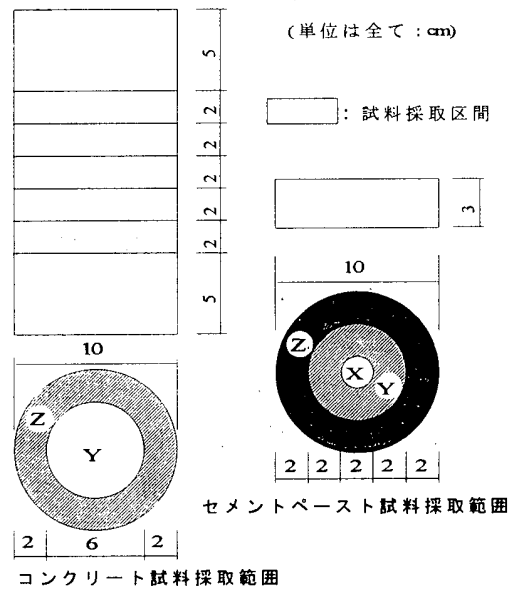

図-1 試料採取位置 c)ポロシチーの測定 : ポロシチーの測定は、水銀圧入法にようた。装 置を図-2 に示す（FISION Instrument 社製ポロシメーターPascal 140 お よび Pascal 240 型 最大圧力は 200MPa)。測定範囲は、細孔径 3.7 $7,500 \mathrm{~nm}$ とし、一回の測定に用いた試料の量は約 $5 \mathrm{~g}$ である。

\section{2-5. モルタルの不溶残分}

モルタルの不溶残分は、(社)セメント協会報告: F-18 に準拠して測 定した。なお、測定した試料は、水セメント比（35\%、55\%）2 水準、 粗骨材種類（G、L、F） 3 種類、養生方法 $(A 、 C) 2$ 水準および材齢 （1 週、4 週）2 水準を組み合わせたもの計 24 種類とした。

\section{表-1 使用骨材の主要物性}

\begin{tabular}{|c|c|c|c|c|c|c|c|c|}
\hline & 粗粒率 & $\begin{array}{c}\text { 洗 い } \\
\text { 損 失 } \\
(\%) \\
\end{array}$ & $\begin{array}{l}\text { 単位容皘啠 } \\
(\mathrm{kg} / \mathrm{l})\end{array}$ & $\begin{array}{c}\text { 実積率 } \\
(\%) \\
\end{array}$ & $\begin{array}{l}\text { 絶 乾 } \\
\text { 比重 }\end{array}$ & $\begin{array}{l}\text { 表乾 } \\
\text { 比重 }\end{array}$ & 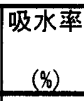 & $\begin{array}{c}\text { 使用時 } \\
\text { 含水率 } \\
(\%)\end{array}$ \\
\hline 川砂 & 2.81 & 1.66 & 1.74 & 67.6 & 2.58 & 2.61 & 1.2 & - \\
\hline 硬質砂岩砕石 & 6.72 & - & 1.54 & 59.2 & 2.61 & 2.64 & 0.9 & - \\
\hline $\begin{array}{c}\text { 膨張頁岩系 } \\
\text { 人工軽量骨材 }\end{array}$ & 6.56 & 0.31 & 0.81 & 62.6 & 1.29 & 1.46 & 13.1 & 26.7 \\
\hline $\begin{array}{c}\text { 石炭灰系 } \\
\text { 人工軽量骨材 }\end{array}$ & 6.53 & 0.42 & 0.82 & 60.6 & 1.34 & 1.56 & 16.6 & 23.8 \\
\hline 試験方法 & $\begin{array}{c}\text { JS A } \\
1102\end{array}$ & $\begin{array}{c}\text { JIS A } \\
1103\end{array}$ & $\begin{array}{c}\text { JIS : A } \\
1104\end{array}$ & $\begin{array}{|cc|}J I S & A \\
1104\end{array}$ & \begin{tabular}{c|} 
JIS A \\
1109
\end{tabular} & \begin{tabular}{|l|}
$\pi S: A$ \\
1110
\end{tabular} & $\begin{array}{c}\text { JS A } \\
1111\end{array}$ & $\begin{array}{c}\text { JIS A } \\
1135\end{array}$ \\
\hline
\end{tabular}

\section{表-2 試料コンクリートの種類および調合概略}

\begin{tabular}{|c|c|c|c|c|c|c|c|c|c|c|c|}
\hline \multirow[b]{2}{*}{$\begin{array}{l}\text { 粗骨材 } \\
\text { 種，類 }\end{array}$} & \multirow[b]{2}{*}{ 㓞号 } & \multirow[b]{2}{*}{$\mathrm{W} / \mathrm{C}$} & \multirow[b]{2}{*}{\begin{tabular}{|c|} 
細 \\
骨 \\
材 \\
率 \\
$(\%)$ \\
\end{tabular}} & \multirow[b]{2}{*}{$\begin{array}{c}\text { 単 } \\
\text { 位 } \\
\text { 水 } \\
\text { 量 } \\
\left(\mathrm{kg} / \mathrm{m}^{3}\right)\end{array}$} & \multicolumn{3}{|c|}{ 絶対容樌 $\left(1 / \mathrm{m}^{3}\right)$} & & \multicolumn{3}{|c|}{ フレッシュコンクリリート性状 } \\
\hline & & & & & & $\begin{array}{l}\text { 細 } \\
\text { 骨 } \\
\text { 材 }\end{array}$ & $\begin{array}{l}\text { 粗 } \\
\text { 骨 } \\
\text { 材 }\end{array}$ & $\begin{array}{l}\text { 混和剂 } \\
\text { 添加量 } \\
\left(\mathrm{kg} / \mathrm{m}^{3}\right)\end{array}$ & $\begin{array}{l}\text { スランプ } \\
(\mathrm{cm})\end{array}$ & $\begin{array}{c}\text { 空気量 } \\
(\%)\end{array}$ & $\begin{array}{c}\text { 単位 } \\
\text { 容積 } \\
\text { 㗨量 } \\
(\mathrm{kg} / l)\end{array}$ \\
\hline 硬 質 & & 35 & & 173 & 156 & 279 & 341 & $7.41^{* 1}$ & 18.6 & 5.1 & 2.35 \\
\hline 砂 岩 & GN & 45 & & 169 & 119 & 288 & 352 & $1.88^{* 2}$ & 19.0 & 7.2 & 2.29 \\
\hline 研 石 & & 55 & & 173 & 99 & 304 & 372 & $1.26^{* 2}$ & 18.5 & 5.2 & 2.32 \\
\hline 膨張 頁 & & 35 & & 172 & 156 & 278 & 339 & $6.4 * 1$ & 18.4 & 5.5 & 2.00 \\
\hline 岩系人工 & LN & 45 & 45 & 171 & 120 & 290 & 355 & $1.14^{* 2}$ & 19.0 & 6.4 & 1.94 \\
\hline 軽量骨材 & & 55 & & 173 & 100 & 304 & 372 & $0.94^{* 2}$ & 19.4 & 5.1 & 1.97 \\
\hline 石炭灰系 & & 35 & & 170 & 154 & 274 & 335 & $6.31^{* 1}$ & 19.8 & 6.8 & 1.98 \\
\hline 人工軽量 & $\mathrm{FN}$ & 45 & & 172 & 121 & 293 & 358 & $1.53^{* 2}$ & 20.0 & 5.7 & 1.97 \\
\hline 骨 材 & & 55 & & 173 & 100 & 305 & 372 & $1.26^{* 2}$ & 18.1 & 5.0 & 1.99 \\
\hline
\end{tabular}

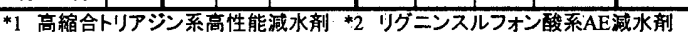

注)調合はすべて空気盟をもとに補正した値

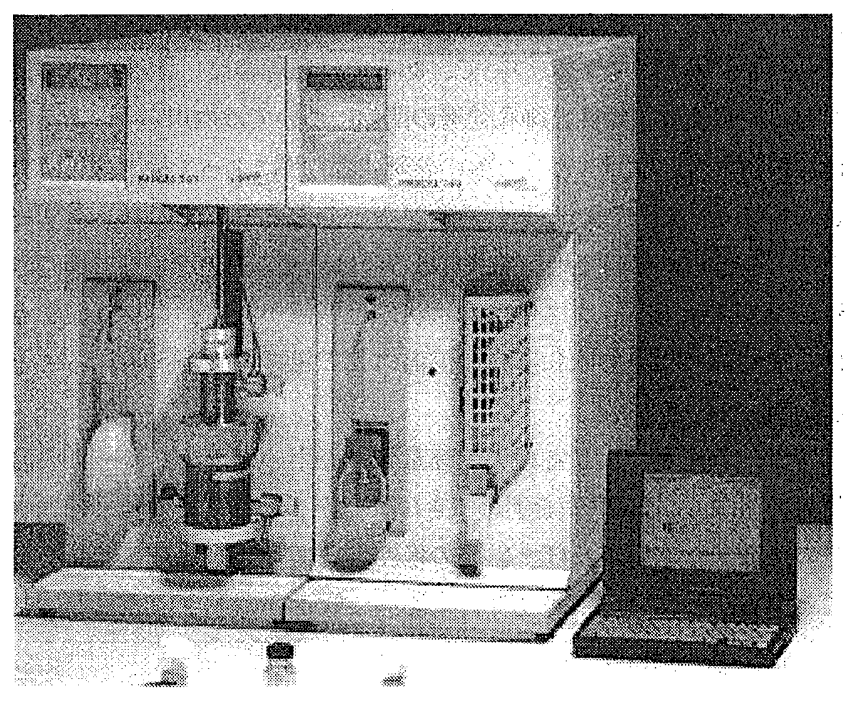

図-2 ポロシメータの外観 

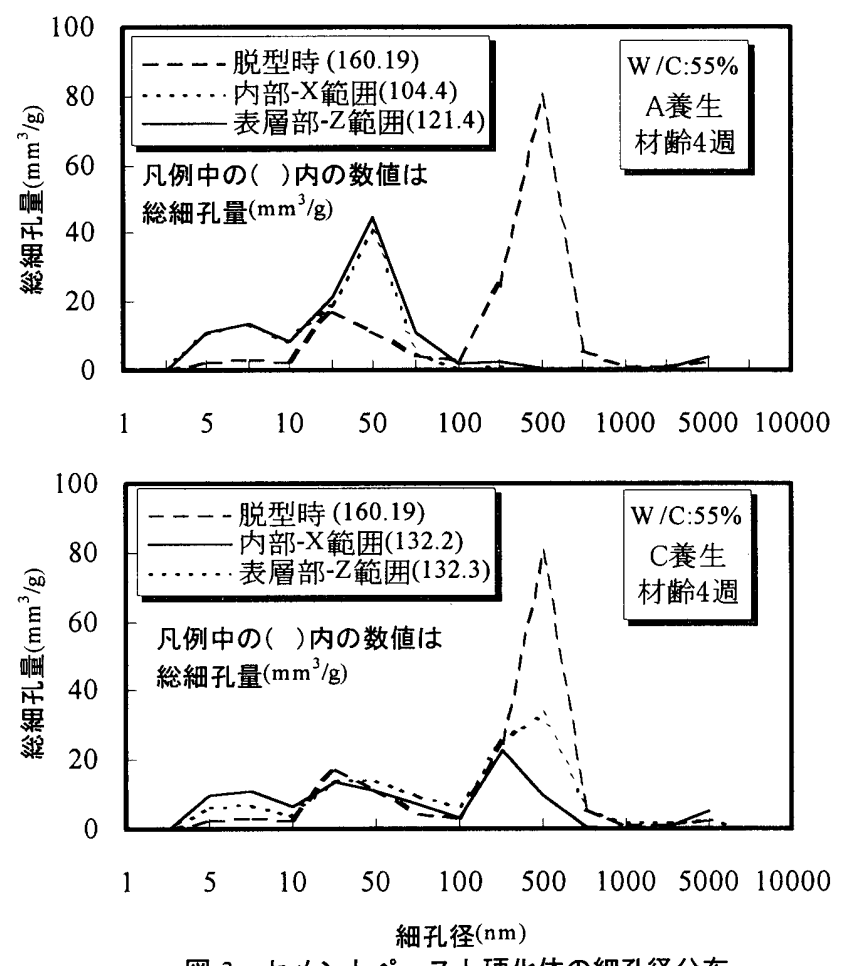

図-3セメントペースト硬化体の細孔径分布

\section{3. 実験結果および検討}

3-1. 養生方法がセメントペースト硬化体の細孔構造に及ぼす影響

養生方法が細孔構造に及ぼす影響について、セメントペースト硬 化体の細孔径分布を一例として水セメント比 $55 \%$ の試料について図3 に示す。水中養生した試験体の細孔分布は、脱型時において $500 \mathrm{~nm}$ 付近で最も多い細孔量を示し、以後材齢の経過により全体的に細孔 分布が小さい径へとシフトしている。この水和反忘の進行に伴う現 象は、養生方法の差異により若干異なっている。気中養生したもの では、細孔径 250 500nm 付近で細孔量が多く、脱型時の細孔量より も減少してはいるが、水中養生した試料に比べると全体的に大きい 径の細孔量が多い。また、水中養生した場合、採取位置の違いはほ とんど細孔分布に影響を及ぼしていないが、気中養生した場合には、 より乾燥をうける表層部のほうが大きい径の細孔量が多い。これは、

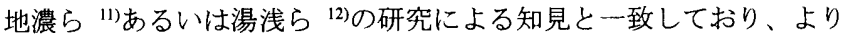
乾燥をうける表層部において水和の進行が緩慢となることによるも のである。なお、以上のような材齢の経過にともなう細孔分布の変 化は水セメント比 $35 \%$ および $45 \%$ の場合でも同様の傾向であった。 本実験の範囲では、水中養生と気中養生の違い、あるいは試料採取 位置の違いによる総細孔量の差は小さく、水和の進行にともなう細 孔分布の小径側へのシフトは総細孔量から判断しにくい。そこで採 取位置の違いが細孔径平均值（全細孔を円柱形と仮定し総細孔量と 比表面積により算出した平均径）に及ぼす影響を図-4に示す。これ によれば、水中養生を行ったものは範囲による差がほとんどないが、 気中養生を行ったものは例外もあるがおおよそ表層の試料のほうが 細孔径平均值は大きくなっており、表層部で水和の進行が内部より も緩慢になっていることが理解できる。また 1 週水中以後気中養生 としたものについては、ほぼ水中養生のものと同様の傾向である。 3-2. コンクリートの水分発散量に及ぼす骨材の影響

各種骨材を用いたコンクリートの経時による水分発散量について

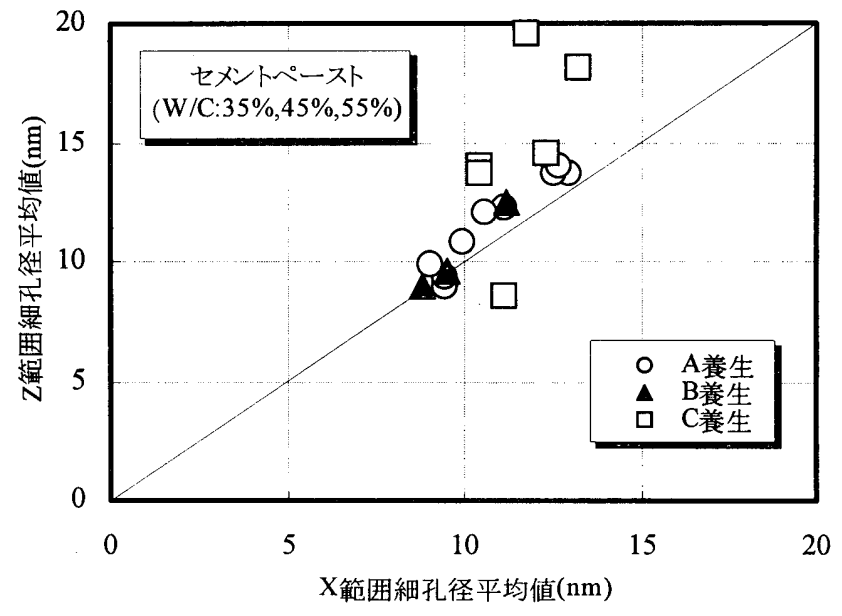

図-4 セメントペースト硬化体の細孔径平均值と採取位置の関係

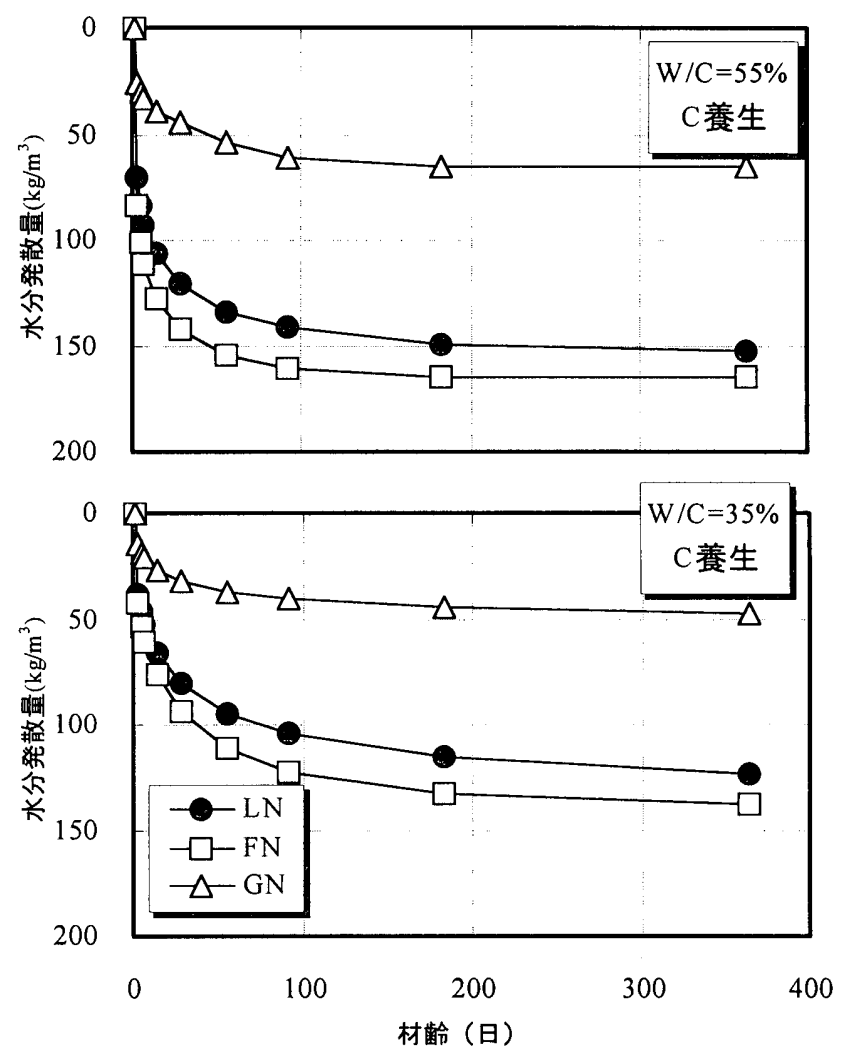

図-5 各種骨材を用いたコンクリートの水分発散量

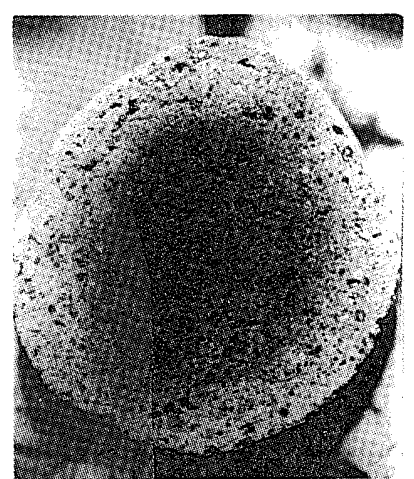

石炭灰系

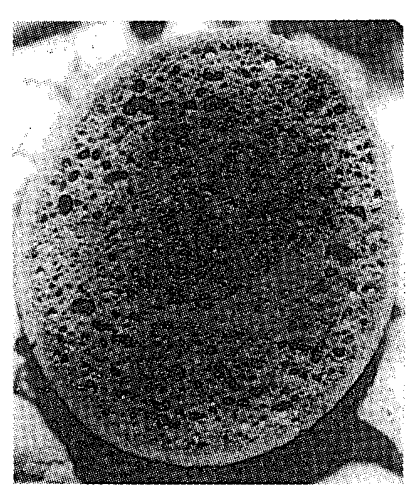

膨張頁岩系
図-6 軽量骨材の外観 
水セメント比 $35 \%$ おび $55 \%$ の気中養生したものを図-5 に示す。乾 燥をうける養生では、脱型時およびそれ以降のコンクリート組織は 水セメント比が小さいほうが緻密であるため同材齢における水分発 散量が小さい。また、乾燥をうけるコンクリートの水分発散はコン クリート内部の湿度と外部の湿度との相関により発散量が左右され ると考えらるが、粗骨材に含水率の大きい軽量骨材を用いた場合に は、普通骨材を用いたものに比べ非常に大きな水分発散量を示して いる。2 種類の軽量骨材を比較すると、水セメント比によらず骨材中 の水分量を含めたコンクリート中の総水量が若干小さい石炭灰系軽 量骨材の方が水分発散量は大きい。2 種類の軽量骨材の外観写真を図 -6に示す。石炭灰系軽量骨材は膨張頁岩系軽量骨材と異なり骨材の 外殻にシェルを有しておらず、また内部の気泡は連続している。こ のことから石炭灰系軽量骨材では骨材内部の水分が膨張頁岩系軽量 骨材に比べて発散しやすく、そのため石炭灰軽量骨材を用いたコン クリートの水分発散量が大きいといえる。

\section{3-3.コンクリートの細孔構造に及ぼす骨材種類の影響}

本実験で行った不溶残分の測定結果を表-3 に示寸。若干使用した 粗骨材種類の違いによるバラツキはみられるが、不溶残分の測定值 から得たモルタル中のペースト重量割合は、いずれの骨材を用いた 場合でも水セメント比 $35 \%$ で 46〜 55\%、水セメント比 55\%で 34〜 40\% の間にあり、測定値の平均值と調合から求めた計算値との誤差は大 きいものでも $8 \%$ 程度である。また、材齢、養生方法および試料採取 位置等の影響も特に認められなかった。そこで本報告では、コンク リートの調合からモルタル中のペーストと細骨材との比を求めて補 正した值を有効細孔量とし、以後の検討を進めることとした。

\section{3-3-1．細孔分布に及ぼす材酫および骨材種類の影響}

各種骨材を用いたコンクリートの細孔分布について水セメント比
$55 \%$ 一例として図-7 に示す。図は養生方法を全材齢水中養生とし たもので、かつ供試体内部（Y 範囲）のものである。これによると、 セメントペースト硬化体の場合と同様に、各種コンクリートとも材 齢の経過により水和反応が進展し、細孔量のピークが小径側に移動 している。石炭灰系軽量骨材を用いたコンクリートは、他に比べて 25 〜50nm の細孔量が小さく、有効総細孔量も小さい。水分発散のない 養生方法であっても骨材の含水率などが変わればコンクリート中の 内部湿度も異なり水和速度が若干異なることも考えられるが、骨材 種類によって異なる細孔量の差は、筆者らでは現在のところ細骨材 の混入などによる実験誤差と考えている。なお、水セメント比 $35 \%$ および 45\%においても、脱型時の細孔径のピークに違いはあるが、 材齢の経過による細孔分布の変化は同様の傾向を示した。

\section{3-2-2．細孔径分布に及ぼす養生方法の影響}

乾燥をうけるコンクリートの細孔径分布を検討するため、全材齢 水中養生および全材齢気中養生とした各種骨材を用いたコンクリー トの細孔分布について水セメント比 $35 \%$ 、材齢 4 週時を一例として 図-8 に示す。脱型後直ちに乾燥をうける気中養生としたコンクリー トでは、供試体内部の細孔分布は、水中養生を行ったコンクリート のそれとほとんど変わりない分布を示した。しかし、気中養生を行 ったコンクリートの表層部では、用いた骨材の種類によって細孔分

表-3 モルタル中のペースト重量割合

\begin{tabular}{|c|c|c|c|c|}
\hline \multirow[t]{2}{*}{ コンクリート } & \multicolumn{4}{|c|}{ ペースト重量割合の範囲および平均值 (\%) } \\
\hline & $\mathrm{W} / \mathrm{C}=35 \%$ & & $\mathrm{~W} / \mathrm{C}=55 \%$ & \\
\hline 類 & 不溶残分測定値 & 計算値 & 不溶残分測定值 & 計算值 \\
\hline GN & $46.73 \sim 51.67(48.88)$ & 47.77 & $38.48 \sim 40.41(39: 44)$ & $\longdiv { 1 3 7 . 9 8 }$ \\
\hline $\mathrm{LN}$ & $47.81 \sim 55.43(51.62)$ & 47.82 & $36.46 \sim 38.59(37.52)$ & 38.13 \\
\hline FN & $46.46 \sim 53.22(48.98)$ & 47.87 & $34.09 \sim 35.32(34.68)$ & 38.05 \\
\hline
\end{tabular}
注2:表中の計算値は調合から求めたもの

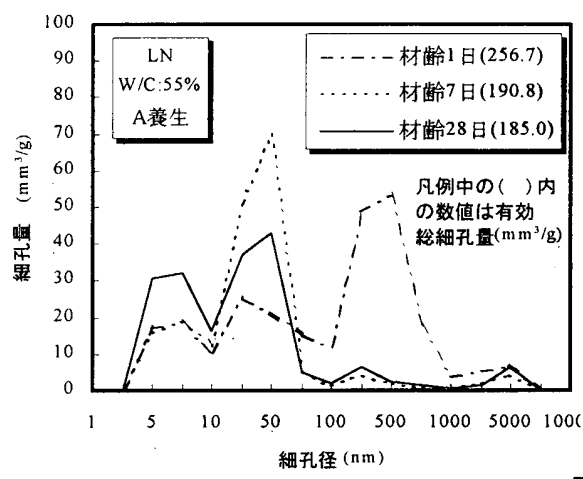

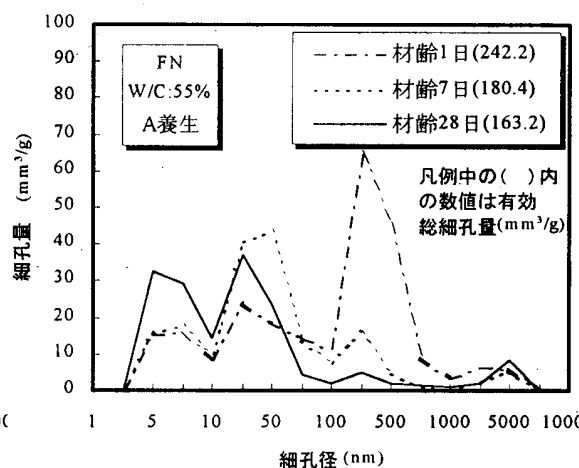

図-7＼cjkstart各種骨材を用いたコンクリートの細孔分布
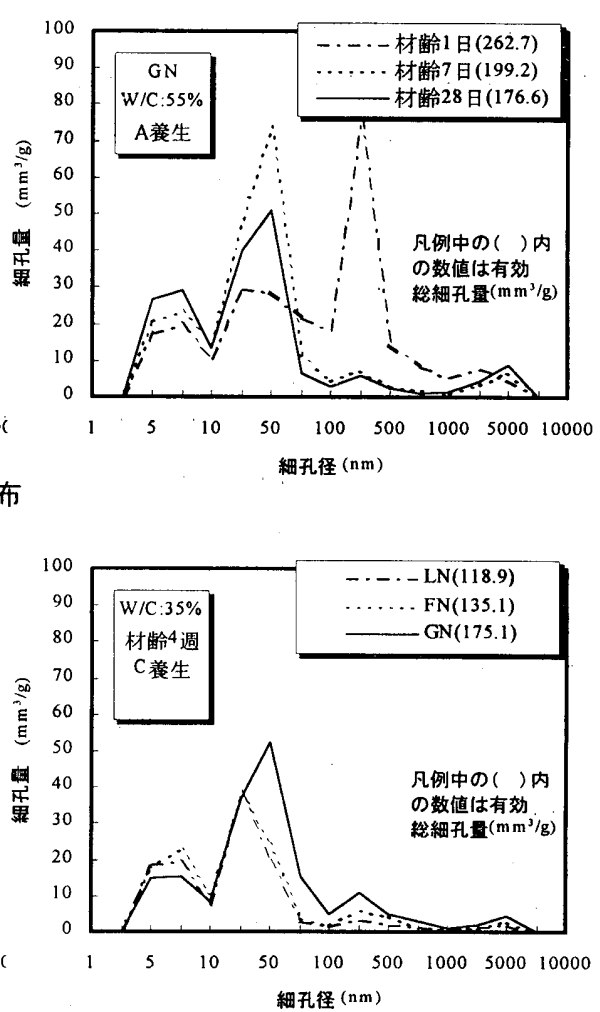

図-8＼cjkstart乾燥をうけるコンクリートの細孔分布 
布が異なった傾向を示した。砕石コンクリートでは、他に比べて大 きい径の細孔量が多く、小さい径の細孔量が少ない細孔分布であっ た。これは、より乾燥をうける表層部において水和の進行が緩慢と なることによるもので 3-1 で述べたセメントペースト硬化体の結果 と一致している。これに対して膨張頁岩系および石炭灰系軽量コン クリートでは、細孔径 25 50nm 付近の細孔量が若干大きいが、細孔 分布は比較的内部のものに近い傾向を示した。

\section{3-3-3．細孔構造に及ぼす水セメント比および骨材種類の影響}

全材齢水中養生および全材蹫気中養生のコンクリートにおける内 部の細孔径平均值の比較を図-9に示す。軽量骨材を用いた 2 種類の コンクリートでは水中養生および気中養生の細孔径平均値は同等の 值であり、養生方法の違いによる影響は認められない。しかし、砕 石を用いたコンクリートでは細孔径平均值が大きい範囲で、気中養 生のほうが水中養生の值よりも大きい。3-1 でも述べたように水セメ ント比が大きいコンクリートでは、水セメント比の小さいものより モルタルマトリックス組織は粗いためコンクリート中の水分は発散 し易く、より内部まで乾燥が進んだことによるためと考えられる。 つまり、本実験の範囲では砕石コンクリートではモルタルマトリッ クス組織が緻密であれば試験体内部では水和反忘の進行が期待でる が、軽量骨材は含水率が砕石に比べて非常に大きいため、水セメン ト比が大きい場合でも内部ではモルタルマトリックス中の湿度が大 きく、水和反応の進行が期待できる。ただし、軽量骨材を用いた場 合でも水分発散は水セメント比の違いによるモルタルマトリックス 組織の緻密さにも左右されるため、軽量骨材による水和反応の進行 についてはより組織が緻密である高強度域において効果が大きいと 考えられる。

\section{3-3-4．表層部の細孔構造に及ぼす骨材種類の影響}

各種コンクリートの細孔径平均值を図-10に示す。これによると、 砕石を用いたコンクリートではセメントペースト硬化体の場合と同 様に、水分発散のない水中養生および封縅養生のコンクリートでは、 内部と表層部の細孔径平均值はほぼ同等の值を示している。これに 対して脱型後ただちに乾燥をうける気中養生のコンクリートでは、 表層部の細孔径平均值は内部の值に比べて大きい值となっており、 乾燥による影響をうけ水和反応の進行が緩慢になっている。1 週水中 以後気中養生のコンクリートでは気中養生のものと同様なものもみ られるが、比較的水中養生したものに近い傾向を示した。一方、含 水率が砕石に比べて大きい軽量骨材を粗骨材として用いた膨張頁岩

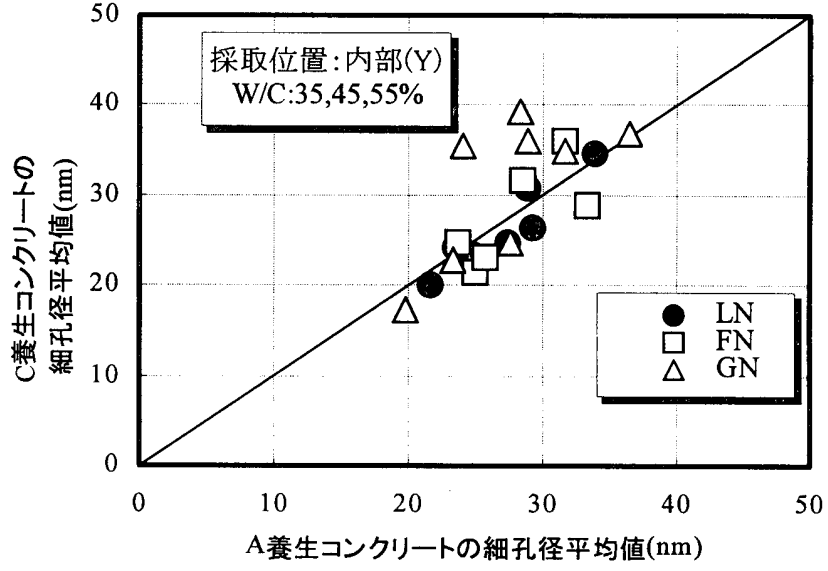

図-9 コンクリートの細孔径平均値に及ぼす養生方法の影響

系および石炭灰系軽量コンクリートの細孔径平均值についてみると、 気中養生とした場合では、膨張頁岩系軽量コンクリートでは砕石コ ンクリートに近い傾向を示した。しかし、石炭灰系軽量コンクリー 卜は表層部の細孔径平均值はやや大きいが、他の骨材を用いたコン クリートと比べると内部との差は小さく、表層部においても細孔構 造の緻密化が進展しているといえる。同程度の含水率で使用した 2 種の骨材によるこの差は、3-2. において述べたように表層に溶融シ エルをもつ膨張頁岩系軽量骨材のほうが骨材内部の水分が石炭灰系 軽量骨材に比べて発散しにくいことに起因する。このような骨材種 類の違いによる細孔構造および水分発散量の違いは耐火性などの性 質に多大な影響を及ぼすと考えられる。

\section{4. 結論}

コンクリートの細孔構造に影響を及ぼす諸要因に関する既往の知 見を確認した上で、軽量骨材を用いたコンクリートに関する検討結 果をまとめると大要以下のことがいえる。

(1) コンクリートの水分発散は、水セメント比、骨材の含水率による 影響が大きい。また、溶融シェルの有無あるいは気泡の連続性とい った骨材特性の違いによっても影響をうける。

（2）乾燥をうけにくい供試体内部では、水セメント比が小さいと骨材 種類によらず組織の緻密化が期待できる。一方、水セメント比が大 きいと内部まで乾燥が進むため粗骨材の含水率の影響をうけ、砕石 コンクリートでは組織の緻密化が緩慢となるが、軽量骨材を用いた

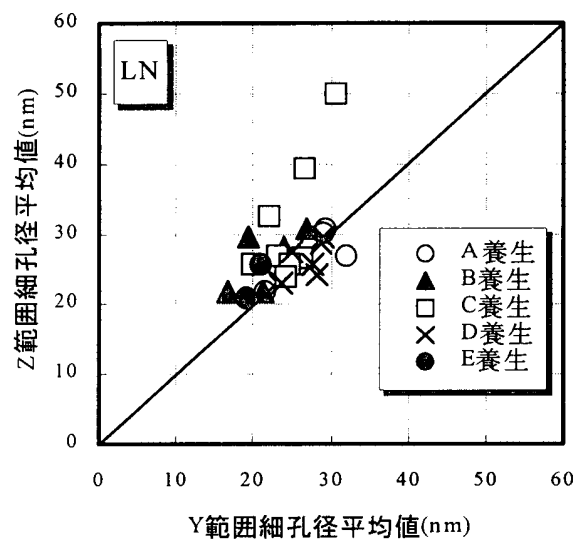

図-10 コンクリートの細孔径平均値に及ぼす養生方法の影響と採取位置の関係

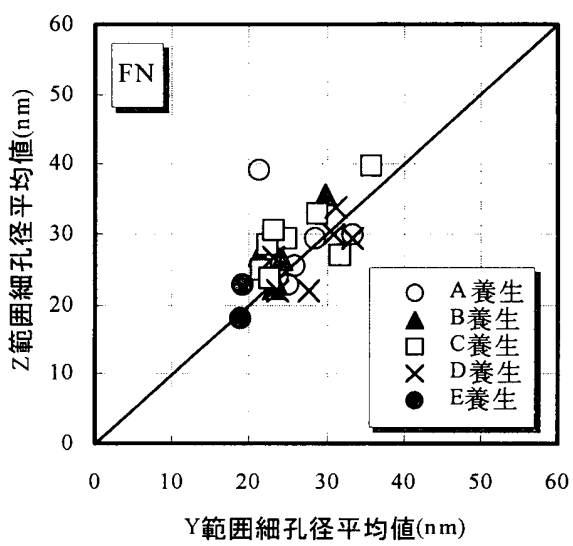

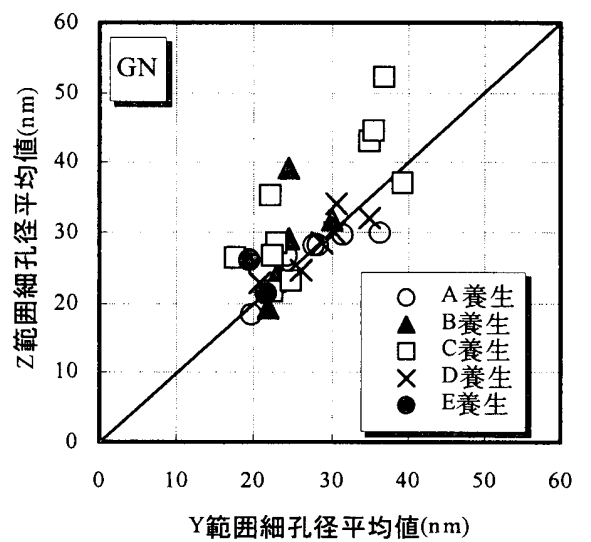

Y範囲細孔径平均値 $(\mathrm{nm})$ 
コンクリートでは組織の緸密化が期待できる。

(3). 軽量骨材中の水分がモルタルマトリックスの細孔構造に及ぼす影 響は、骨材中からの水分発散のし易さによる影響が大きい。溶融シ ェルのある骨材を用いた場合、乾燥をうけやすい表層部で組織の緻 密化が緩慢となる。溶融シェルのない石炭灰系軽量骨材を用いた場 合、乾燥をうけやすい表層部においても組織の緻密化が期待できる。

\section{【謝辞】}

本研究を行うにあたり日本コンサルタント株式会社 山口氏、中村 氏、石川氏、日本メサライト工業株式会社、九電産業株式会社、ポ ゾリス物産株式会社、株式会社エヌエムビーならびに 1995 年度明治 大学卒論生穒野信治君および若本昌已君に多大なる協力を賜りまし た。ここに厚く謝意を表します。

\section{【参考文献】}

[1] 内川 浩:組成と構造の観点から見た硬化セメントペースト,モ ルタルおよびコンクリートの類似点と相違点 セメント・コンク リート,No.507,pp.33〜45,1989.5

[2] 鎌田 英治、吉野 利幸:空隙率および水和度によるコンクリー 卜の強度の表示 セメン技術年報 32 pp.216 220,1978

[3] 吉野 利幸、鎌田 英治、田畑 雅幸、柳 敏幸: コンクリート強 度の空隙率依存性を応用したコンクリート強度推定法の提案 セメント技術年報 33 pp.249 252,1979

[4] 鎌田 英治、大内 一之、吉野 利幸:硬化セメントペーストの凍 害と細孔構造の役割について セメン技術年報 33 pp.292 295,1976

[5]鎌田 英治、吉野 利幸、寺井 靖人:コンクリートの強度と細孔 構造に関する研究 セメン技術年報 34 pp.256〜259,1977

［6］李 長江、依田 彰彦、横室 隆、セメントペーストの細孔構造 および圧縮強度に及ぼす高炬スラグ微粉末の影響 日本建築学 会構造系論文報告集 No.506,pp.1 6,1998

[7] 田中 享二、内田昌宏、大森 修、橋田浩、湯浅 昇:塗り床の ふくれ発生機構の一考察 日本建築学会構造系論文報告集 No.488、pp.25 30,1996

[8] 田中 享二、内田 昌宏、大森 修、Keesun BAE:塗り床のふくれ 発生に及ぼす下地コンクリートの影響 日本建築学会構造系論 文報告集 No.493、pp.1 7,1997

[9] 橋田 浩、田中 享二小池 迪夫:打設直後から乾燥途中におけ るコンクリートの含水状態(仕上げ材下地としてのコンクリート 含水率の検討その 1) 日本建築学会構造系論文報告集 No.412、pp.1 $\sim 8,1990$

[10］田沢 栄一、米倉 垔州夫、寺本 尚夫、森下 全人:細孔構造の 相違がコンクリートの乾燥収縮およびクリープに及ぼす影響 セメン技術年報 $40 \quad$ pp.131 133,1984

[11] 地濃 茂雄、平野 隆、仕入 豊和:養生条件とコンクリートの 表層部の細孔構造 セメン技術年報 $38 \quad$ pp.266 269,1984

[12］湯浅 昇、笠井 芳夫、松井 勇:表層コンクリートのの品質の 評価(乾燥を受ける表層コンクリートの細孔構造の経時変化)日本 建築学会大会学術講演梗概集 A, pp. 199 200,1994

[13] 湯浅 昇、松井 勇、逸見 義男、佐藤 弘和:仕上げ材のはがれ に及ぼす下地コンクリートの含水率、細孔構造の影響 コンクリ 一下工学年次論文報告集第 18 巻 第 1 号, pp.573 278,1996

［14］湯浅 昇、笠井 芳夫、松井 勇、逸見 義男、佐藤 弘和:仕上 げ材を施すコンクリート床スラブの含水率、細孔構造 日本建築 学会構造系論文報告集 No.504 pp.7 13,1998.2

[15］村上 祐治、山下 英俊、鈴木 篤、:コンクリートの塩分透水に
おける乾燥および微細構造の影響 コンクリート工学年次論文 報告集 Vol.14,No.1,pp.675 680,1992

[16] 湯浅 昇、笠井 芳夫、松井 勇:表層コンクリート品質の検討 日本建築学会大会学術講演梗概集 A, pp.449 450,1993

[17］菊池”雅史、向井 毅:石炭灰軽量骨材の構造用コンクリート骨 材としての適用性に関する研究(第 1 報)日本建築学会構造系論文 報告集、第 402 号, pp. $27 \sim 36,1989,9$

［18］菊池 雅史、榎本 浩士、小山 明男、多田 克彦:石炭灰軽量骨 材を用いたコンクリートの高強度化・高耐久化に関する検討(そ の1.骨材特性が庄縮強度に及ぼす影響) 1992 年度日本建築学会 関東支部研究報告集 pp.173 176

[19］菊池 雅史、榎本 浩士、谷部 徹、三原 崇明: 石炭灰軽量骨 材を用いたコンクリートの高強度化・高耐久化に関する検討(そ の4.ポロシチー、耐火性状について) 日本建築学会大会学術講 演梗概 集(関東)A、p.p399 400,1993.9

[20] 向井 毅、菊池，雅史、山盛，智広: 石炭灰軽量骨材を用いた コンクリートの基礎的性質に関する研究(その 4. . 水分発散が諸強 度に及ぼす影響について） 日本建築学会大会学術講演梗概集(関 東)A、p.p431 432,1988.10

[21］㐘池 雅史、成岡·優:石炭灰軽量骨材を用いたコンクリートの 基礎的性質に関する研究(その 6..乾燥に伴う内部歪みについて) 日本建築学会大会学術講演梗概集(中国)A、p.p839～840,1990.10

（1998年 3 月 10 日原稿受理，1998年 7 月 17 日採用決定） 